\title{
Research on the Relationship between British and American Cultural Differences and American Literature Comment
}

\author{
Hongling Wang \\ Gansu Industry Polytechnic College, Tianshui, Gansu, China
}

\begin{abstract}
The influence of cultural differences by race and treat people with an understanding of the work will be carried out from different angles, which leads to the same people for a work of literary criticism. Expand article on the impact of cultural differences between British and American English and American literary criticism on this topic research, by the characteristics of English and American Literature and American Literature and commentary of the corresponding description. It is to analyze the impact of cultural differences on the Anglo-American literary criticism, so that people understand the culture differences in the importance of the influence of the Anglo-American literary criticism.
\end{abstract}

Keywords-anglo-American cultural differences; angloAmerican literary criticism; relations

\section{DEVELOPMENT OF AN ANGLO-AMERICAN LITERATURE}

\section{A. Development of English literature}

Development of English literature has gone through the Anglo - Saxon several different stages, literary review, Neoclassicism, Romanticism, and Realism and so on.

In medieval times, the Anglo-Saxon and Jutes invaded from northern Europe were to the United Kingdom, people from "Beowulf," the epic Beowulf can learn to kill the trolls for safety of the people, fighting Duron, evil forces in the conquest of nature process at the expense of his own. As for structure of this literature poetry more complete picture of vivid description, people can easily find the process of reading Old English poetry features. Sixth century, Christianity into England, from Bede wrote, "Religious History of the British people," because the contents of a certain historicity and philosophical is widely reading. Although the Danes invaded to some extent to make such academic destroyed, but in the late ninth century, Wessex king Dan's did not forget the case of the anti-academic revitalization, from the local history of English literature. Neoclassical period in English literature was before beginning the second half of the eighteenth century and highly respected poet Pope's representative works are usually more ironic, more to vent Siyuan majority. Essayist neoclassical period usually had a certain spirit of the Enlightenment; they opened up the periodical essays and literary realism novels these two new areas. Compared to the journal concerned, prose novels featuring the British have a significant impact on the European continent, such as Defoe's "Robinson Crusoe" for the British realist fiction laid the foundation for the development of Swift's "Gurley
Gulliver's Travels "in English novel also greatly stimulated people's imagination.

Romantic period was to Blackburn as a representative of English literature, he wrote the poem "Songs of Innocence," "Songs of Experience", "four gods" which reflects his support for the French Revolution. Unlike this subtle poetry of the eighteenth century literature, they pay more attention to people's imagination and inspired by a sense of religious respect. Among the many writers effort during the Romantic literature English literature reached its peak of development, these literary works reflect the characteristics of the United Kingdom, the impact on future generations of world literature also has far-reaching significance.

Realism is a French painter Gustave Courbet and writers put together in the next column husband in the 1850s, as one of the basic realism literature and art creation methods, and Romanticism in parallel position. As its name, literary realism period is usually more realistic, not relying on conjecture, imagination and ideals to influence the objective process of literary works. For unrealistic and utopian, are to be the attitude of opposition.

\section{B. Development of American literature}

American literature richer masculinity with the expression of diverse and relatively is close to the voice of the people. There have been a total of three times in the development and prosperity in American literature, American literature in the process of development, there are about ten writer won the Nobel Prize for Literature.

American colonial literature to some extent is influenced by English literature from Michael Zweig Wales Worth • Anne - Blaze Ritter, Edward • Taylor's literary works can be seen a bit of English literature traces.

In a separate revolution generated a lot of revolutionary poetry, American ethnic literature is on this production. Such changes and development not only created the American essayist and poet, and promoted cultural independence but also to some extent had independent of the political.

Let the end of the Civil War be developing in the direction of American literature of realism, romanticism followed by decline. Because capitalism was after the Civil War in the stage of free competition, which to some extent, so that the people and the idea have become liberal writers, literary works of this period also has certain optimism. However, after the nineties, due to people's democracy doubt lead to increased criticism of the reality of works, including racial discrimination, collusion between 
government and big business occupies most of the content, utopian socialist thought into them.

More great development of American literature was during the two wars, the various literary genres have also appeared. but in general, these literary works are contradictions of capitalist society and the spiritual world a certain description, and which reflects the problem, Modernist literature and left-wing literature as the biggest literary trends during the two wars, the development of world literature had a significant impact.

Post-World War II American literature appeared in the biographies and more detailed, more prosperous development of literary biography, which is written in • Ideal "• Henry James" a typical representative. Because there are too many Jews in World War II by the Japanese brutally murdered, with the explosion of the atomic bomb in Hiroshima event, which makes American writer and literary critic shocked, beliefs also will be shaken. Under this background, the war novels have been widely circulated

\section{FEATURES OF BRITISH AND AMERICAN LITERATURE}

The so-called Anglo-American literature refers to a use of the public art methods appear to represent the English in the UK, the US and China, the main content is the text of the United States and Britain to reflect real life. English as a world language more widely used, not only has a profound text AUO function, and the use of English literature makes up the British Friends of the text that has a profound effect on. According to different literature show Friends, and the Anglo-American literary performance style is very diverse, including theatrical, literary criticism, fiction and so on.

\section{A. Features of English literature}

English literature has a profound history, you can see the different historical and political content in English literature content in these social realities are different degrees of influence on English literature, English literature led at every stage have carried out different text change.

From the perspective of the development of the British in the 16th century, it is along with the expanding British nationalism, as in the Renaissance stage of Britain, during this period there have been many outstanding literary works. In the ensuing 17th century and there lived through the metaphysical and the Cavaliers sent two stages, making faith, doubt with this complex ideas and romantic echoes. In the 18th century and early 19th century, classical romanticism in English literature is to the late appeared in many fields more about marital problems, feminist issues.

In the 20th century, along with Ireland literary review, English Literature went to a new stage of development. From the perspective of historical development, the characteristics of the history of English literature as a profound, complex changes. In the creation of British literature, literary font received the influence of British politics, economic development and religious ideas, this effect makes the creation of English literature during the writing had to show different levels of content, but also makes a more regular English Literature.

\section{B. Features of American literature}

The formation of a pre-war local literature had psychology literature and black literature, and so the article, before World War II has experienced a renaissance phase Modernism. In the latter part of World War II, along with the rapid development of the United States, its leading the United States appeared in a variety of literary forms, according to the art form of literature can be divided into romanticism, realism and modernism in three stages.

The earliest American literature is a literary expression isolated by British literature, American literature in the early stages of development can be seen in addition to the strong performance of American literature English literature style. But as the United States continues to develop, in the Revolutionary War, and so the impact of cultural creation is getting out of the influence of American literature English literature, American literature has developed a unique style, toward the development of a wide range of art forms. Thus, American literature in the text is more diversified, multiangle characteristics of the development.

\section{Anglo-American literary review}

Anglo-American literary criticism is primarily a practice so thoroughly studied English and American literature of the use of a text literal literary theory. By studying the text to reveal the development of the law of British and American literature, and provides the basis for the art of writing English and American Literature. About AngloAmerican literary criticism, the main target is to use English commentary literature creation. Meanwhile, the AngloAmerican literary criticism literary works of artistic expression, depending on the content of the comments into the fiction, poetry reviews, theater reviews, and so on. Anglo-American Literary Review's main purpose is through the work of ideological content, forms, writing style and so forth, and has a full range of interpretation

\section{CULTURAL DIFFERENCES IMPACT FOR AMERICAN LITERATURE}

\section{A. Cultural differences affect the development of the carrier of the Anglo-American literary criticism}

Britain's cultural and historical development of long has a good development of traditional national culture. And English as a cultural and historical development of this case has its own advantages, because it is the transmission of traditional culture, literature has a very good performance capabilities. Therefore, many literary critics in the British literature review when very careful use of language, perhaps out of the case caused the English worship, fear of contamination due to improper use of British English language status. So the British literary critic reviews have always been relatively rules, lack of personality. British English American English is derived, although in essence and British English relatively unchanged, but the role of freedom, democracy and the new country, the United States in the fight for independence in the development of economic, political and cultural systems are freshmen. 
American English also as a new thing, in the development process will be with innovative features. And the United States more successful democratic revolution in the political and economic aspects of the history of not leaving a big problem. The surface that is reflected in the language literary critic commenting on American Literature, the comparison with personality and creativity. Innovation on the language of freedom, spirit and American democracy are closely linked.

\section{B. Cultural differences on English and American literature and it contains comments}

Comments in English literature are between tradition and away from the traditional struggle. Shakespeare's "Hamlet" in Hamlet in revenge struggling to "survive or perish," this issue is not fully demonstrated his assertive personality, while the British literary criticism of this period also have such features. 17-18 century, the British literary criticism is from religious to create absurd way that reflects the heritage and tradition of struggle out. After the 20th century, the British literary criticism had more changes that are obvious. The overall analysis, the British literary critics in addition to Eagleton has an influential literary critic that does not appear. English literary criticism goes toward the development of a modern, post-colonial, feminist direction. Literary theory literature reviews of previous achievements were re-analyzed, and it had built a new, literary theory and current society to adapt.

Analysis of American literature review cannot pay attention to the study of American literature, literary criticism is because after the birth of literature. America is a colonial country, literature by European literature, it especially influenced by Indian and British literature. The author believes that American literature has its own characteristics, although it's subject to many factors, but the most important factor is the United States itself. American literature and its commentary are a separate entity.

\section{Effect of the historical and cultural differences between British and American literary criticism}

For English literature, in the cultural and historical development, cultural and historical characteristics of the humanistic tradition, but with abstinence, theocratic compared to literary criticism among more conservative view of humanism, which British bourgeois revolution in culture history of compromise are inseparable. Such as Shakespeare in their own literature reviews, the analysis of the works of humanism is more propaganda, which can be said to be typical of the British literary commentary on literary criticism after England had an impact, but also the formation of the British stable the traditional concept of humanism comment. But with social development, innovation becomes increasingly important, conservative humanistic outlook has also been a certain amount of doubt. American Literary Review for humanistic views seem radical uniqueness as well, it is because the United States and the United Kingdom is different, with no cultural and historical baggage, but also failed to cultural and historical issues. At the same time the United States is to fight for freedom and cultural freedom, independence of the United States to form an atmosphere of literary criticism in the development of easy to play, so the American literary reviews for the humanistic point of view is more radical, and it even showed a particularly innovative concept of humanism .

\section{CONCLUSION}

The Anglo-American literary criticism affect many factors, cultural differences are more important factors, differences in the Anglo-American cultural development are through the carrier, Cultural Differences, historical and cultural differences are in comparison, we can conclude that the Anglo-American cultural differences in American Literature review plays an important role domination. British and American literature is in order to make a correct comment; you need to combine cultural differences critic traceable history and background of the development between the two countries that are produced by appropriate comments. English literary criticism with respect to the American literary critic who used to grow a lot has a certain rationality color, while the degree of freedom of American literature in terms of innovation and expression of ideas much better than England. British and American Literature has its own characteristics, the two cannot be replaced, and for people living environment, atmosphere and social development of the country's culture have important significance.

\section{REFERENCES}

[1] Gao Li. Anglo influence of cultural differences on the AngloAmerican literary criticism [J] writers, 2012,22: 210-211.

[2] Wu Jing. Impact of cultural differences on the Anglo-American Anglo-American Literary Review Analysis [J] intelligence, 2015,03: $282-283+285$

[3] Ding Hui. Impact of cultural differences on the Anglo-American literary criticism [J] Hubei Correspondence University, 2015,01: 182183.

[4] Gai Yingying. Impact of cultural differences on the Anglo-American literary criticism [J] era literature (the second half), 2012,02: 183-184.

[5] Zhang Yuee. On cultural differences between English and American Literature review the impact [J] Technology wind, 2014,18: 230.

[6] Miao Yin. Impact of cultural differences on English and American literature reviews [J] writers, 2013,24: 168-169. 